\title{
Inhibitory effect of Hypericum ascyron on pro-inflammatory responses in lipopolysaccharide-induced Raw 264.7 Cells
}

\author{
Eun-Jin Hong ${ }^{1} \cdot$ Hye-Jin Park ${ }^{1}$ (D) Na-Hyun Kim ${ }^{1} \cdot$ Jae-Bum Jo$^{1} \cdot$ Jae-Eun Lee $^{1} \cdot$ \\ Su-Bin Lim ${ }^{1} \cdot$ Dong-Hyun Ahn' ${ }^{2}$ Hee-Young Jung ${ }^{3}$ - Young-Je Cho'

\section{Lipopolysaccharide로 유도된 Raw 264.7 cell에서 물레나물(Hypericum asctron)의 Pro-inflammatory 억제 효과}

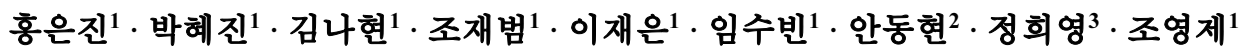

Received: 12 September 2017 / Accepted: 25 October 2017 / Published Online: 31 December 2017

(C) The Korean Society for Applied Biological Chemistry 2017

\begin{abstract}
Hypericum ascyron has long been used as medicinal plant and recent studies reported that $H$. ascyron has anti-diabetic, anti-oxidant, and anti-bacterial effects. In this study, inhibitory effect from $H$. ascyron on pro-inflammatory responses has been investigated. $H$. ascyron was extracted at optimal extraction condition. Total phenolic contents in water and $90 \%$ ethanol were 29.75 and $31.82 \mathrm{mg} / \mathrm{g}$, respectively. Hyaluronidase inhibitory activity of $H$. ascyron extracts $(50-200 \mu \mathrm{g} / \mathrm{mL}$ phenolics) was $0.00-14.81 \%$ and $15.33-47.49 \%$, respectively. In cell viability, cell toxicity was shown at concentration of $100 \mu \mathrm{g} / \mathrm{mL}$ and $30 \mu \mathrm{g} / \mathrm{mL}$ of water and $90 \%$ ethanol extract. Therefore, $10-50 \mu \mathrm{g} / \mathrm{mL}$ in water extracts and $5-20 \mu \mathrm{g} / \mathrm{mL}$ in ethanol extracts was selected each for further study. Inducible nitric oxide synthase (iNOS)
\end{abstract}

Young-Je Cho $(\square)$

E-mail: yjcho@knu.ac.kr

${ }^{1}$ School of Food science \& Biotechnology/Food \& Bio-Industry Research Institute, Kyungpook National University, 80 University Street, Bukgu, Daegu 41566, Republic of Korea

${ }^{2}$ Department of Food Science and Technology, Pukyong National University, Busan 48513, Republic of Korea

${ }^{3}$ School of Applied Biosciences, Kyungpook National University, Daegu 41566, Republic of Korea

This is an Open Access article distributed under the terms of the Creative Commons Attribution Non-Commercial License (http://creativecommons. org/licenses/by-nc/3.0/) which permits unrestricted non-commercial use, distribution, and reproduction in any medium, provided the original work is properly cited. derived nitric oxide (NO) and cyclooxygenase (COX)-2-derived prostaglandin $\mathrm{E}_{2}\left(\mathrm{PGE}_{2}\right)$ protein expression inhibitory effect of extracts were inhibited in a dose dependent manner, significantly. Also, the pro-inflammatory cytokines inhibitory effect such as tumor necrosis factor- $\alpha$, nterleukin (IL)- 6 and IL-1 $\beta$ were decreased in the dose dependent manner. The results indicate that $H$. ascyron extracts reduced inflammatory responses in lipopolysaccharide-induced 264.7 cells via the regulation of the iNOS, COX-2, NO, $\mathrm{PGE}_{2}$, and pro-inflammatory cytokines. Therefore, $H$. ascyron extracts have significant anti-inflammatory effect and a source as therapeutic materials.

Keywords Anti-inflammation · Cyclooxygenase-2 - Cytokine · Hypericum ascyron · Inducible nitric oxide synthase

\section{서 론}

예로부터 생리활성을 가지는 새로운 기능성 신소재의 탐색과 검 증을 위한 연구가 체계적으로 진행되고 있으며, 식물자원 및 식 품 소재로부터 질병 예방과 치료를 목적으로 새로운 소재 개발 에 대한 관심이 증가하고 있다(Jhoo 2008). 식물체내의 생리활 성물질의 대부분은 페놀성 화합물로 구성되어있고 이들의 기능 은 항산화, 암, 당뇨, 심혈관계 질환, 신경변성 질환 등 그 외 에 다양한 질병을 예방하는데 유익한 역할을 한다고 보고되고 있다(Joo 등, 2007; Cho 등, 2008). 현대인의 식생활이 점차 서 구화로 바뀌게 되면서 비만, 환경오염, 스트레스 등으로 인한 
염증 관련 질환이 증가하고 있는 추세인데, 염증은 생체 조직 의 물리적인 외상, 유해한 화학 물질, 미생물학적 약제 등 외부 자극에 의해 손상되는 부위를 재생하려는 정상적인 복구기전으 로 면역세포가 활성화되면서 일어나는 면역 계통의 복합적인 반 응으로 발생한다. 하지만 염증이 과발현되는 경우, 과민성 면역 반응을 일으키거나 그로 인한 조직과 장기의 파괴, 기능 소실 등 생체에 불리한 결과를 가져 올 수 있으며 만성 염증의 경우 파킨슨 질환, 노인성 치매, 류마티스 관절염, 동맥경화 등 다양 한 질환들의 원인이 된다(Moncada 등, 1991; Ryu 등, 2011; lee 등, 2016a;). Lipopolysaccharide (LPS)는 외부의 여러 이물 질 중 toll like receptor 4 (TLR 4)에 의해 인식되는 박테리아 내독소이며, macrophage를 활성화시켜 염증반응을 일으키는 주 요한 인자 중 하나이다. 활성화된 TLR 4는 세포 내부의 여러 단계의 신호 전달 과정을 활성화시키며, 그 중 활성화된 NF-KB 는 핵 내로 이동하여 염증성 cytokine인 tumor necrosis factor (TNF)- $\alpha$, interleukin (IL)-1 $\beta$, IL-6와 cyclooxygenase (COX)2, inducible nitric oxide synthase (iNOS)와 같은 염증성 단백 질의 유전자 발현을 증가시키고 최종적으로 nitric oxide $(\mathrm{NO})$ 와 prostaglandin $\mathrm{E}_{2}\left(\mathrm{PGE}_{2}\right)$, cytokine을 생성시켜 통증, 부종, 발열, 염증 부위로 염증 반응을 매개하는 것으로 알려져 있다 (Tak과 Firestein 2001; Kang 등, 2011a; Kim 등, 2014). 지금 까지 개발된 합성 항염증제로는 aspirin, indomethacin, arachidonic acid 등이 있으며 이들은 주로 prostanoid의 생합성을 촉진하는 $\mathrm{COX}$ 효소 억제를 통하여 해열, 진통, 항염증 효과를 나타낸다. 그러나 합성 항염증제를 장기간 복용 시 위산분비 증가와 점액 보호 감소, 혈소판 응집 반응 감소 등 부작용이 발생할 수 있 어 보다 안전하고 효과 있는 천연물 유래의 항염증 치료제의 개발이 필요한 실정이다(Makins와 Ballinger 2004; Dangne 등, 2006). 따라서 각종 부작용을 유발하는 합성 식 - 의약품을 대 체하기 위해 천연자원으로부터 기능성 효능이 있는 식품, 생약, 화장품을 개발하고자 하는 연구가 많이 진행되고 있다(Jeong 등, 2013).

물레나물(Hypericum ascyron L.)은 물레나물과의 다년초로 대 활심초, 방심초, 일지전, 대정혈 등의 다양한 이름으로 불리고 있다. 주로 한국, 중국, 일본 등에 산과 들에 분포되어 있으며 어린잎은 식용으로 쓰고, 뿌리, 잎, 종자는 약용으로 쓰인다. 효 능으로는 지혈, 패독, 소종 등이 보고되고 있으며 그 중 hypericin은 식물성 항생제로 상처, 궤양, 뾰루지 등에 널리 쓸 수 있다고 알려져 있으며, 서양에서는 우울증 환자 치료에 널 리 이용된다(Han 등, 2002). 성분으로는 flavonoid, xanthone, triterpene 등이 보고되어 있으며 현재 물레나물에 대한 선행연 구로는 주로 steroid 및 flavonoid의 성분 분리에 대한 연구 (Park 등, 2000), 분획물을 이용한 식중독 미생물 증식 억제 물 질 분리를 통한 식품개발(Han 등, 2002), 항산화와 항당뇨, 항 균에 대한 연구(Kang 등, 2011b)가 보고되고 있으나 염증에 대 한 연구는 부족한 실정이다.

따라서 본 연구에서는 물레나물의 염증 억제 효과를 측정하고 자 Raw 264.7 cell에 LPS 자극으로 염증 반응을 유도시킨 뒤 물 레나물 추출물에 의해 염증반응에 관여하는 $\mathrm{NO}$ 와 $\mathrm{PGE}_{2}$ 생성량, $\mathrm{iNOS}$ 및 $\mathrm{COX}-2$ 의 발현 억제 정도, pro-inflammatory cytokine인 $\mathrm{TNF}-\alpha, \mathrm{IL}-6, \mathrm{IL}-1 \beta$ 의 생성 억제를 통하여 나타내는 항염증 효과 를 바탕으로 천연 염증 치료제로써 이용 가능성을 확인하였다.

\section{재료 및 방법}

\section{실험재료}

본 실험에서 사용한 물레나물은 시중에서 구입하여 사용하였으 며, 시료는 $50{ }^{\circ} \mathrm{C}$ dry oven에서 건조하여 $40 \mathrm{mesh}$ 로 분쇄한 다음 진공 포장하여 $4{ }^{\circ} \mathrm{C}$ 에서 저온저장하며 시료로 사용하였다.

\section{시약 및 기기}

세포 배양용 시약들은 Hyclone (Logan, UT, USA)사의 dulbecco's modified eagles medium (DMEM), fetal bovine serum (FBS), penicillin-streptomycin solution 등을 구입하여 사용하였으며, lipopolysaccharides from salmonella (LPS), thiazolyl blue tetrazolium bromide (MTT)와 dimethyl sulfoxide (DMSO)는 Sigma (St. Louis, MO, USA)사에서 구입하여 사용하였다. Griess reagent system은 Promega (Madison, WI, USA)사, primary antibody와 secondary antibody는 Cayman (Ann Arbor, MI, USA), BD Bioscience (San Diego, CA, USA), Santa cruze biotechnology (Dallas, TX, USA)에서 각각 구입 하였다. TNF- $\alpha$, interleukin (IL)- $1 \beta$ 와 IL-6의 enzyme-linked immunosorbent assay (ELISA) kit는 R\&D systems a biotechne brand (Minneapolis, NE, USA)에서 구입하여 사용하였 고, 그 외의 시약들은 특급 시약을 사용하였으며 UV/vis spectrophotometer (Optizen 3220UV Mecasys, Daejeon, Korea), centrifuge (Hanil, Incheon, Korea), ELISA reader (BMG lab tech, Ortenberg, Germany) 등을 사용하여 측정하였다.

\section{추출물의 제조}

시료 추출은 열수 추출물은 건조된 물레나물 분말 $5 \mathrm{~g}$ 에 증류 수 $100 \mathrm{~mL}$ 를 가하고 액이 $50 \mathrm{~mL}$ 가 될 때까지 가열, 증발시킨 후 shaking incubator에서 $120 \mathrm{rpm}$ 으로 24시간 동안 상온교반 추출하였다. Ethanol 추출물은 시료에 각 농도별 ethanol 50 $\mathrm{mL}$ 를 가하여 $120 \mathrm{rpm}$ 으로 24시간 동안 상온교반 추출하였으며 추출액은 Whatman No. 1 filter paper (GE healthcare life sciences Piscataway, NJ, USA)로 여과한 후 rotary vacuum evaporator (Eyela NE, Tokyo, Japan)에서 농축하여 ethanol을 모두 제거한 뒤 phenolic compounds 농도에 맞추어 효소 실험 을 진행하였으며, cell 실험 시 추출하여 동결 건조한 시료를 사 용하였다.

\section{Total phenolic compound 함량 측정}

각 추출물의 total phenolic compound는 Folin과 Denis(1921) 의 방법으로 측정하였으며, 시료 $1 \mathrm{~mL}, 95 \%$ ethanol $1 \mathrm{~mL}$, 증 류수 $5 \mathrm{~mL}$ 를 넣은 후 $1 \mathrm{~N}$ Folin-Ciocalteu reagent $0.5 \mathrm{~mL}$ 를 첨가하여 섞은 후 $5 \% \mathrm{Na}_{2} \mathrm{CO}_{3}$ 용액 $1 \mathrm{~mL}$ 를 가하여 암실에서 1시간 방치하여 발색시키고, UV-visible spectrophotometer로 $725 \mathrm{~nm}$ 에서 흡광도를 측정하여 gallic acid를 이용한 표준곡선 으로 양을 환산하였다.

\section{Hyaluronidase 저해 (항염중) 효과 측정}

Hyaluronidase 저해활성 측정은 Reissig 등(1995)의 방법으로 측 정하였으며, sodium-hyaluronic acid (HA)에서 형성된 Nacetylglucosamine을 유도체 glucoxazoline로 변형시킨 다음 p- 
dimethylamino benzaldehyde로 발색시켜 흡광도를 측정하였다. $50-200 \mu \mathrm{g} / \mathrm{mL}$ phenolic compounds 농도의 시료 $0.1 \mathrm{~mL}$ 에 0.1 $\mathrm{M}$ acetate buffer $(\mathrm{pH} 3.5)$ 에 녹인 hyaluronidase $(7,900 \mathrm{U} / \mathrm{mL})$ $0.05 \mathrm{~mL}$ 을 혼합하여 $37^{\circ} \mathrm{C}, 20$ 분간 반응시킨 뒤 $12.5 \mathrm{mM}$ $\mathrm{CaCl}_{2} 0.1 \mathrm{~mL}$ 을 가하여 혼합한 후 다시 20 분간 반응시켰다. 0.1 $\mathrm{M}$ acetate buffer $(\mathrm{pH} 3.5)$ 에 녹인 기질 $(12 \mathrm{mg} / \mathrm{mL}) 0.5 \mathrm{~mL}$ 을 넣고 $38{ }^{\circ} \mathrm{C}, 45$ 분 동안 반응시킨 다음 $0.4 \mathrm{~N}$ potassiumtetraborate $0.1 \mathrm{~mL}$ 와 $0.4 \mathrm{~N} \mathrm{NaOH}$ 용액 $1 \mathrm{~mL}$ 를 첨가하여 3 분 동안 water bath에서 반응 후 완전히 냉각하여 $600 \mathrm{~nm}$ 에서 투과율을 측정 하였다. 대조구는 시료 대신 증류수 $0.5 \mathrm{~mL}$ 를 넣어 반응시켰으 며, 저해율 $(\%)$ 은 (1-시료의 투과율/대조구의 투과율 $) \times 100$ 으로 계산하였다.

\section{항염중 효과 측정을 위한 세포배양}

Mouse macrophage cell line인 Raw 264.7 cell은 한국세포주은 행 (Korean Cell Line Bank)에서 구입하였으며, DMEM에 Hyclone사의 FBS를 $10 \%$, Hyclone사의 $100 \mathrm{U} / \mathrm{mL}$ penicillin 및 $100 \mu \mathrm{g} / \mathrm{mL}$ streptomycin $1 \%$ 를 혼합한 배지를 사용하여 37 ${ }^{\circ} \mathrm{C}, 5 \% \mathrm{CO}_{2}$ incubator에서 72 시간 동안 배양하였다. Cell 배양 dish에 cell의 밀도가 $23 \times 10^{6} / \mathrm{mL}$ 정도가 되게 계대 배양하여 $5 \% \mathrm{CO}_{2}$ 조건으로 cell 상태를 유지하였다.

\section{MTT assay에 의한 세포 독성 측정}

세포 독성 측정은 Carmichael 등(1987)의 방법에 준하여 측정 하였으며 Raw 264.7 cell을 48 well plate에 $5 \times 10^{3}$ cells $/ \mathrm{mL}$ 으 로 분주하고 $5 \% \mathrm{CO}_{2}$ incubator에서 24시간 동안 배양한 뒤 시 료를 농도별로 조제하여 첨가한 후 동일한 조건으로 24시간 배 양하였다. 여기에 $3 \mathrm{mg} / \mathrm{mL}$ 농도로 제조한 MTT 용액 $0.5 \mathrm{~mL}$ 를 첨가하여 4시간 배양한 후 배양액을 제거하고 각 well에 $\mathrm{DMSO} 0.5 \mathrm{~mL}$ 를 가하여 실온에서 10 분간 반응 시킨 뒤 ELISA reader로 $540 \mathrm{~nm}$ 에서 흡광도를 측정하였다. 세포 독성 측정은 시료 용액의 첨가군과 무첨가군의 흡광도 감소율로 나 타내었다. 대조군은 시료와 동일한 양의 $\operatorname{DMEM}(-)$ 배지를 첨 가하여 동일한 조건으로 배양하였다. Cell viability $(\%)=($ 시료첨 가군의 흡광도/대조군의 흡광도) $\times 100$ 으로 계산하였다.

\section{Nitric oxide (NO) 생성량 측정}

$\mathrm{NO}$ 측정은 cell supernatant을 안전한 형태인 nitrate로 환원시켜 griess reagent System (Promega)을 사용하여 측정하였으며, 96 well plate에 $5 \times 10^{4}$ cells $/ \mathrm{mL}$ 을 분주하여 $37^{\circ} \mathrm{C}, 5 \% \quad \mathrm{CO}_{2}$ incubator에서 24시간 배양한 다음, PBS로 washing하여 상등액 을 제거한 뒤 무혈청 배지를 분주하고 LPS $1 \mu \mathrm{g} / \mathrm{mL}$ 는 normal 군을 뺀 모든 well에 넣어서 자극시켰다. 이후 농도별로 시료를 조제하여 첨가한 후 $37^{\circ} \mathrm{C}, 5 \% \mathrm{CO}_{2}$ incubator에서 24시간 배 양시켰다. 24시간 뒤 supernatant을 모아 griess reagent로 반응 시킨 후 $540 \mathrm{~nm}$ 의 흡광도로 측정하였다. 측정한 값은 $\mathrm{NO}$ 생성 율로 환산하여 $\%$ 로 나타내었다.

\section{$\mathrm{PGE}_{2}$ 생성량 측정}

Raw 264.7 cell을 배양하여 6 well에 cells $\left(5 \times 10^{5} / \mathrm{mL}\right)$ 을 분주 하고 24시간 뒤에 LPS $1 \mu \mathrm{g} / \mathrm{mL}$ 와 농도별로 제조한 sample을
처리한 후 18 시간 뒤 세포 배양액을 취하여 $\mathrm{PGE}_{2}$ 을 측정하였 다. 수거된 상층액은 측정 전까지 $-70{ }^{\circ} \mathrm{C}$ 에서 보관하였고 $\mathrm{PGE}_{2}$ 의 함량은 ELISA kit (R\&D system, Minneapolis, MN, USA)를 사용하여 측정하였으며, 함량은 표준물질의 반응으로부 터 얻어진 표준곡선을 이용하여 환산하였다.

\section{Western blot에 의한 iNOS, COX-2 protein expression 측정} 필요한 만큼의 Raw 264.7 cell을 모아 양을 계산하여 6 well plate에 $5 \times 10^{5}$ cells $/ \mathrm{mL}$ 를 분주하고 $37^{\circ} \mathrm{C}, 5 \% \mathrm{CO}_{2}$ incubator에 서 24시간 배양한 뒤, PBS로 washing하고 무혈청 배지와 LPS $1 \mu \mathrm{g} / \mathrm{mL}$ 을 normal군을 뺀 모든 well에 넣어서 자극시켰다. 이 후 농도별로 조제한 시료를 첨가하고 $37^{\circ} \mathrm{C}, 5 \% \mathrm{CO}_{2}$ incubator 에서 18 시간 배양시켰다. 이후 상등액을 제거한 뒤 차가운 $\mathrm{PBS}$ 로 2회 세척한 후 M-PER buffer (mammalian protein extraction reagent)를 넣어 scrapper로 protein을 용출시켰다. 수확한 protein 은 $4{ }^{\circ} \mathrm{C}, 13,000 \mathrm{rpm}$ 에서 20 분간 원심 분리하였다. 원심 분리 하여 얻은 상층액을 새로운 micro tube에 모은 뒤 $\mathrm{BCA}$ protein assay kit를 이용하여 protein 양을 계산하여 western blot용 sample로 만들어 사용하였다. 이후 전기영동 기기를 이 용하여 $10 \%$ SDS-polyacrylamide gel에 sample을 $120 \mathrm{~V}$ 로 1시 간 30 분 동안 loading하여 protein 크기별로 분리하였고 분리된 protein은 PVDF membrane으로 옮기기 위해 transfer 기기를 이 용하여 $60 \mathrm{~V}, 2$ 시간 30 분 동안 transfer하였다. 이후 ponceau $\mathrm{S}$ 에 2 분 정도 담근 후에 band를 확인하고, $1 \times \mathrm{TBST}$ 로 3 회 씻은 후 blocking buffer로 1시간 blocking하여 background를 제거시 켰다. Primary antibody (iNOS, COX-2)는 1:1,000으로 희석하 여 $4{ }^{\circ} \mathrm{C}$ 에서 overnight 하여 붙인 후 $1 \times \mathrm{TBST}$ 로 3 번 씻어주고 secondary antibody (mouse anti-rabbit IgG HPR)를 1:1,000으 로 1 시간 30 분 붙인 다음 $1 \times \mathrm{TBST}$ 로 3 번 씻어주었다. 이후 enhanced chemiluminescence kit와 반응시켜 image analyzer (C300, Azure biosystems, Dublin, Ireland)을 이용하여 band를 현상하여 정량화하였다.

\section{Pro-inflammatory cytokine 생성량 측정}

Raw 264.7 cell을 배양하여 6 well에 cells $\left(5 \times 10^{5} / \mathrm{mL}\right)$ 을 분주 하고 24 시간 뒤에 LPS $(1 \mu \mathrm{g} / \mathrm{mL})$ 와 농도별로 제조한 sample을 처리한 후 18 시간 동안 시간대 별로 세포 배양액을 취하여 cytokine을 측정하였다. 수거된 상층액은 측정 전까지 $-70{ }^{\circ} \mathrm{C}$ 에 서 보관하였고, TNF- $\alpha$, IL-6, IL- $1 \beta$ 등의 함량을 ELISA kit (R\&D system, Minneapolis, MN, USA)를 사용하여 측정하였 으며 각 cytokine의 함량은 표준물질의 반응으로부터 얻어진 표 준곡선을 이용하여 환산하였다.

\section{통계처리}

본 실험의 결과는 6 회 반복하여 측정한 평균값을 나타내었으며 평균 \pm 표준편차로 나타내었다. 통계처리는 SPSS 22 for windows (Statistical Package for Social Science, Chicago, IL, USA) 프로그램을 이용하여 통계처리 하였고, 분산분석 Duncan's multiple range test one-way ANOVA로 95\% 수준 에서 유의성을 검정하였다. 


\section{결과 및 고찰}

\section{용매 종류, 농도 및 용출 시간에 따른 phenolic compounds 함량}

Phenolic compounds는 식물계에 널리 분포되어 있으며 다양한 구조와 분자량을 가지는 2 차 대사산물의 하나로 다양한 생리기 능을 가지는 것으로 알려지면서 현재까지 천연소재로부터 생리 활성물질을 추출하려는 연구가 다양한 방향으로 활발히 이루어 지고 있다(Jo 등, 2016). Phenolic compounds는 식물의 종류와 부위에 따라 성분과 함량의 차이를 보인다고 보고 되어지고 있 으며 추출용매와 추출에 사용된 용매의 농도, 추출방법, 시간에 따라서 유효성분의 추출 효율이 달라진다고 보고된 바 있다 $(\mathrm{Kim}$ 등, 2009b). 따라서 본 연구에서는 효율적으로 phenolic compouds 함량을 용출하기 위해 물레나물을 용매별, 농도별, 시간별로 다 양한 추출 방법을 통하여 최적 추출 조건을 확인하였다. 먼저 추출용매를 달리하여 추출물의 total phenolic compounds 함량 을 측정한 결과 Fig. $1 \mathrm{~A}$ 에서와 같이 물레나물을 methanol 용매 에 추출 하였을 때 total phenolic compounds 용출량이 31.33 $\mathrm{mg} / \mathrm{g}$ 으로 사용한 용매 중 가장 많은 양의 phenolic이 용출되었 고 이어 열수 추출물이 $29.75 \mathrm{mg} / \mathrm{g}$ 으로 두 번째로 높은 phenol 이 용출되었다. 이후로는 ethanol $>$ butanol $>$ acetone 순으로 용 출되었다. 추출물을 식품과 화장품으로 적용시키기 위해 인체에 유해하지 않은 추출 용매인 열수와 ethanol을 추출 용매로 선정 하여 이후 실험을 진행하였다. 열수와 ethanol을 추출 용매로 효
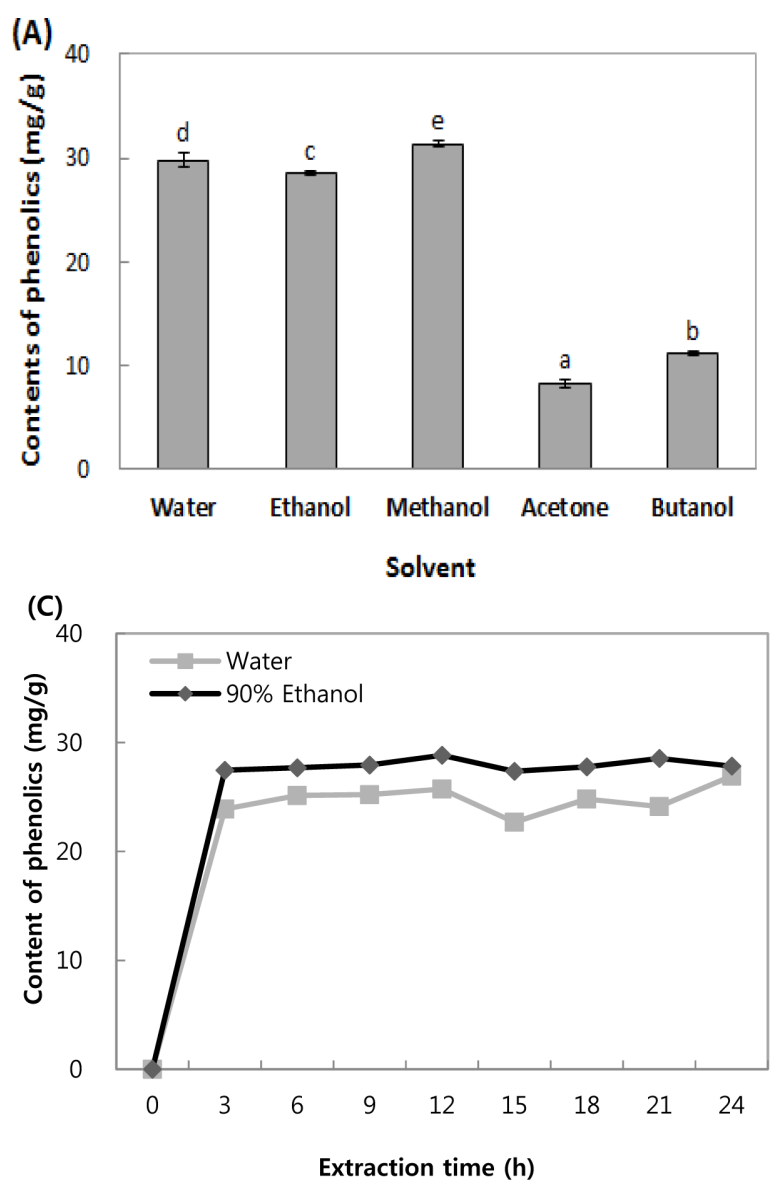

과적인 phenolic 성분 추출을 위해 $10-100 \%$ 의 ethanol 농도로 추출하였다. 그 결과 Fig. $1 \mathrm{~B}$ 에서와 같이 $40-90 \%$ ethanol 농도 에서 유사한 phenol 함량을 보였으나, 통계처리 결과 $80,90 \%$ 농도의 ethanol에서 유의적인 차이 없이 높은 phenolic compounds 함량이 용출 되었으며 수치상으로 $90 \%$ ethanol에서 $31.82 \mathrm{mg} / \mathrm{g}$ 으로 가장 많은 phenolic compounds 함량이 용출되었 으므로 열수와 $90 \%$ ethanol을 용매로 선정하여 다음 실험을 진 행하였다. 추출 시간에 따라 용출되는 phenolic 함량을 알아보 기 위해 열수와 $90 \%$ ethanol을 추출 용매로 24시간 동안 3시 간 간격으로 용출되어 나오는 total phenolic compound 함량을 측정한 결과 Fig. $1 \mathrm{C}$ 에서와 같이 열수 추출물은 24 시간 추출했 을 때 $26.91 \mathrm{mg} / \mathrm{g}, 90 \%$ ethanol 추출물은 12 시간 추출 했을 때 $28.82 \mathrm{mg} / \mathrm{g}$ 으로 가장 많은 phenol 함량이 용출되었다. 위 결 과를 바탕으로 염증 억제에 대한 기능성 탐색을 위하여 물레나 물을 열수와 $90 \%$ ethanol을 최적 추출 농도로 하여 열수는 24 시간, $90 \%$ ethanol은 12시간을 추출하여 sample로 사용하였다.

\section{추출물의 hyaluronidase 저해 (항염중) 효과}

신체의 연골과 피부 등에 포함되어 있는 고분자 다당류인 $\mathrm{HA}$ 는 염증반응에 관여하여 상처 치유에 중요한 역할을 한다. 그 러나 고분자 HA는 hyaluronidase (HAase)에 의해 저분자의 $\mathrm{HA}$ 로 분해되며 그로 인해 inflammation, fibrosis, collagen deposition, 알러지 유발을 일으키는 것으로 알려져 있다(Cha와 Lee 2004). 따라서 물레나물의 hyaluronidase 저해 효과 실험을

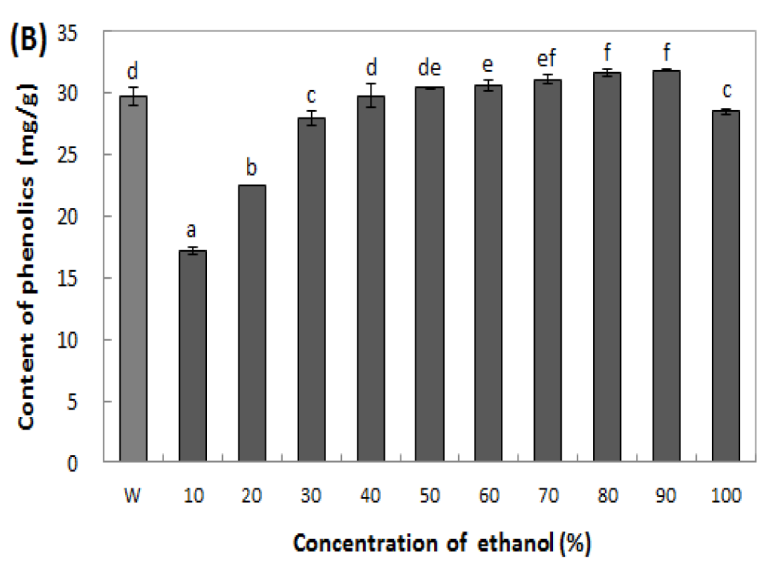

Fig. 1 Effect of different solvent (A), ethanol concentration (B) and extraction time $(\mathrm{C})$ on extraction of total phenolic compounds content in extracts from Hypericum ascyron. Mean \pm standard deviation $(n=6)$. Means with different letters (a-e) above the bars are significantly different at $p<0.05$ by a Duncan's multiple range test 


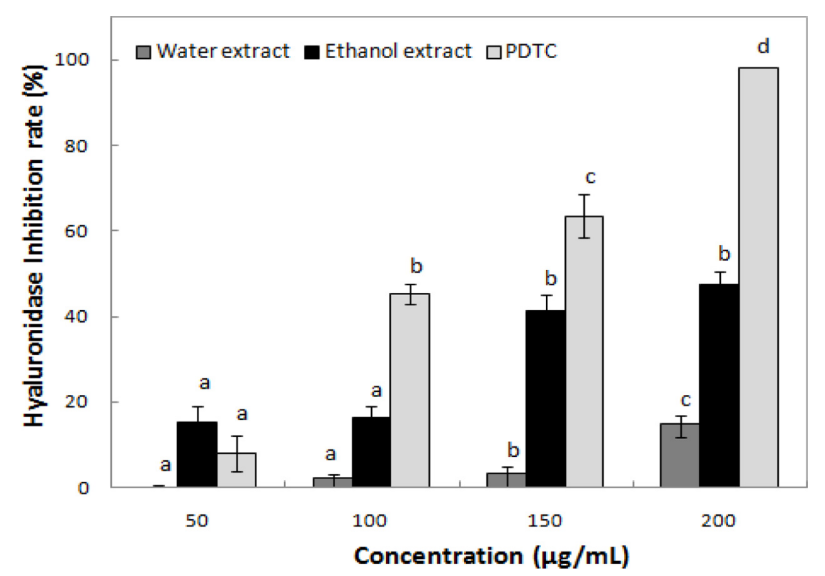

Fig. 2 Inhibition activity on hyaluronidase from extracts of $H$. ascyron. Mean \pm standard deviation $(n=6)$. Means with different letters (a-d) above the bars are significantly different at $p<0.05$ by a Duncan's multiple range test

통하여 고분자 형태의 $\mathrm{HA}$ 를 유지시키는 항염증 효과를 보고자 다음 실험을 진행하였다. 측정 결과 Fig. 2에서와 같이 물레나 물의 열수와 $90 \%$ ethanol 추출물 $50-200 \mu \mathrm{g} / \mathrm{mL}$ phenolic 농도 에서 각각 $0.00-14.81 \%, 15.33-47.49 \%$ 의 저해 효과를 나타내었 으며, 모두 농도 의존적으로 저해 효과가 증가하는 경향을 나 타냈다. 염증 저해 물질로 알려진 ammonium pyrrolidinedithiocarbamate를 positive control로 사용하여 측정한 결과와 비교했 을 때 물레나물 추출물이 보다 낮은 저해 효과를 보였지만, Cho (2015)가 보고한 쇠무릎 잎 ethanol 추출물이 $4,000 \mu \mathrm{g} / \mathrm{mL}$ 농도 에서 $30.20 \%$ 의 저해 효과를 보였고, 숙지황 열수 추출물은 HAase 저해 활성을 전혀 나타나지 않았으며, $40 \%$ ethanol 추 출물은 $200 \mu \mathrm{g} / \mathrm{mL}$ phenolic 농도에서 약 $5 \%$ 로 낮은 저해 효과 를 나타낸 보고(Cho 2012)와 비교했을 때 물레나물 추출물이 저농도에서 높은 hyaluronidase 저해 활성을 나타내어 매우 우 수한 효능을 가진 것으로 판단하였다. HAase활성을 억제하는 기능을 가진 물질들에는 flavonoid, tannins, curcumines 등이 알려져 있는데 물레나물의 hyaluronidase 저해 활성은 물레나물 에 함유되어 있는 flavonoid 성분에 의해 높은 HAase 저해 활 성을 나타낸 것으로 판단되었다(Kushwah 등, 1978).

\section{추출물의 Raw 264.7 cell에 대한 독성 평가}

염증반응에 중요한 역할을 수행하는 macrophage cell에 대한 물 레나물 추출물의 효과를 확인하기 위하여 Raw 264.7 cell에 대 한 독성과 세포 생존율에 미치는 영향을 확인해보았다. 물레나 물의 열수 추출물과 $90 \%$ ethanol 추출물을 $5,10,20,30,50$, $100 \mu \mathrm{g} / \mathrm{mL}$ 농도로 처리하여 MTT assay를 시행한 결과 Fig. 3 에서와 같이 물레나물 열수 추출물은 $50 \mu \mathrm{g} / \mathrm{mL}$ 까지는 $90 \%$ 이 상의 cell viability를 나타내었으며, $100 \mu \mathrm{g} / \mathrm{mL}$ 의 처리농도에서 $81 \%$ 로 생존율이 감소하여 약간의 독성이 있는 것으로 관찰되 었다. $90 \%$ ethanol 추출물은 $30,50,100 \mu \mathrm{g} / \mathrm{mL}$ 농도에서는 각각 $48.00,16.00,15.00 \%$ 로 유의적으로 세포 생존율이 감소하 는 경향을 나타내어 세포 독성이 있는 것으로 판단하였다. 위 결과를 바탕으로 본 연구에서는 $90 \%$ 이상의 생존율을 나타낸 물레나물의 열수 추출물 $5,10,30,50 \mu \mathrm{g} / \mathrm{mL}, 90 \%$ ethanol 추출물 $5,10,20 \mu \mathrm{g} / \mathrm{mL}$ 를 선정하여 이후 실험을 진행하였다.

\section{추출물의 nitric oxide (NO) 억제 효과}

$\mathrm{NO}$ 는 대부분 $\mathrm{iNOS}$ 에 의해 생성되며, 생성된 $\mathrm{NO}$ 는 bacteria를 제거하는 역할을 하지만 과하게 생성될 경우 염증을 일으켜 유 전자 변이, 조직과 신경 손상을 유발한다(Kim과 $\mathrm{Kim} 2015)$. 따 라서 물레나물 추출물의 $\mathrm{NO}$ 생성 억제 효과를 측정한 결과 Fig. 4와 같이 나타났다. LPS 단독 처리구 기준으로 LPS와 함 께 물레나물의 열수 추출물과 $90 \%$ ethanol 추출물을 처리하였을 때, 두 추출물 모두 농도 의존적으로 $\mathrm{NO}$ 생성량이 유의성 있 게 감소하는 경항을 보였다. 열수 추출물은 $50 \mu \mathrm{g} / \mathrm{mL}$ 농도에서 는 $80 \%$ 이상으로 매우 높은 억제 효과를 나타내었다. $90 \%$ ethanol 추출물 또한 $20 \mu \mathrm{g} / \mathrm{mL}$ 농도에서 $70 \%$ 이상의 높은 억 제 효과를 나타냈다. 이상의 결과를 통해 $90 \%$ ethanol 추출물 이 열수 추출물 보다 낮은 농도에서 높은 NO 억제 효과를 보 임으로써 더 뛰어난 효과를 나타내는 것을 확인할 수 있었다. Yoon 등(2011)은 황금 열수 추출물이 $50 \mu \mathrm{g} / \mathrm{mL}$ 농도에서 약 $50 \%$ 이하의 $\mathrm{NO}$ 생성 억제 효과를 나타냈었다고 보고했으며, $\operatorname{Nam}(2014)$ 은 산짚신나물 $70 \%$ ethanol 추출물이 $25,50 \mu \mathrm{g} / \mathrm{mL}$ 농도에서 각각 $8.00,31.50 \%$ 억제한다고 보고했다. 이와 비교 했을 때 물레나물의 두 추출물이 같은 농도에서 보다 높은 $\mathrm{NO}$ 생성 저해 효과를 나타내어 염증성 관련 질환의 치료 및 예방 을 위한 활용 가능성을 기대 할 수 있었다.
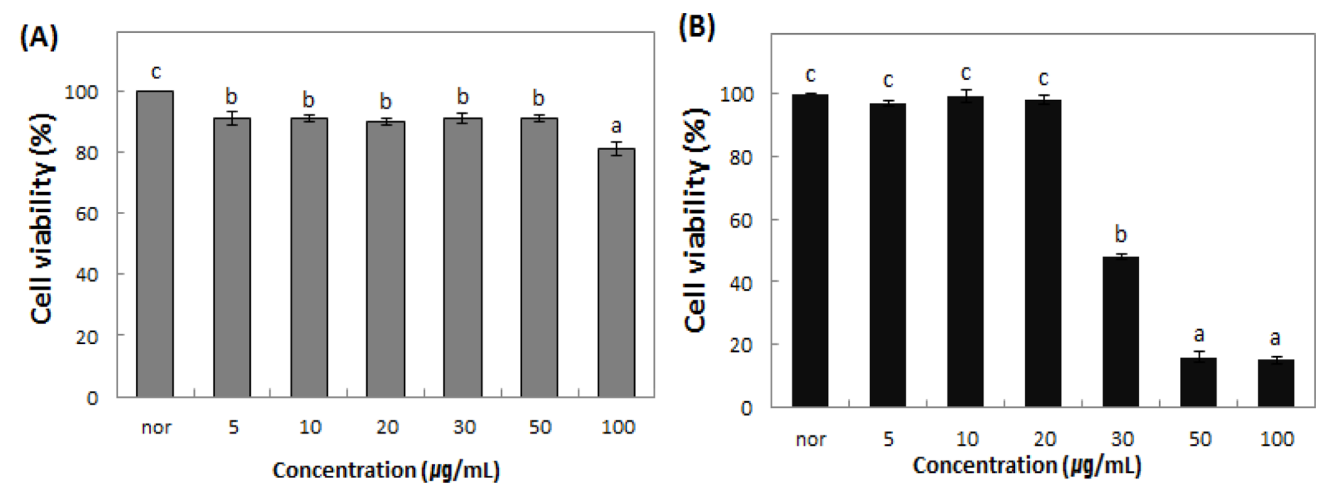

Fig. 3 Cell viability of H. ascyron extracts on raw 264.7 cell. (A) Water extract, (B) $90 \%$ ethanol extract. Mean \pm standard deviation $(n=3)$. Means with different letters (a-e) above the bars are significantly different at $p<0.05$ by a Duncan's multiple range test 

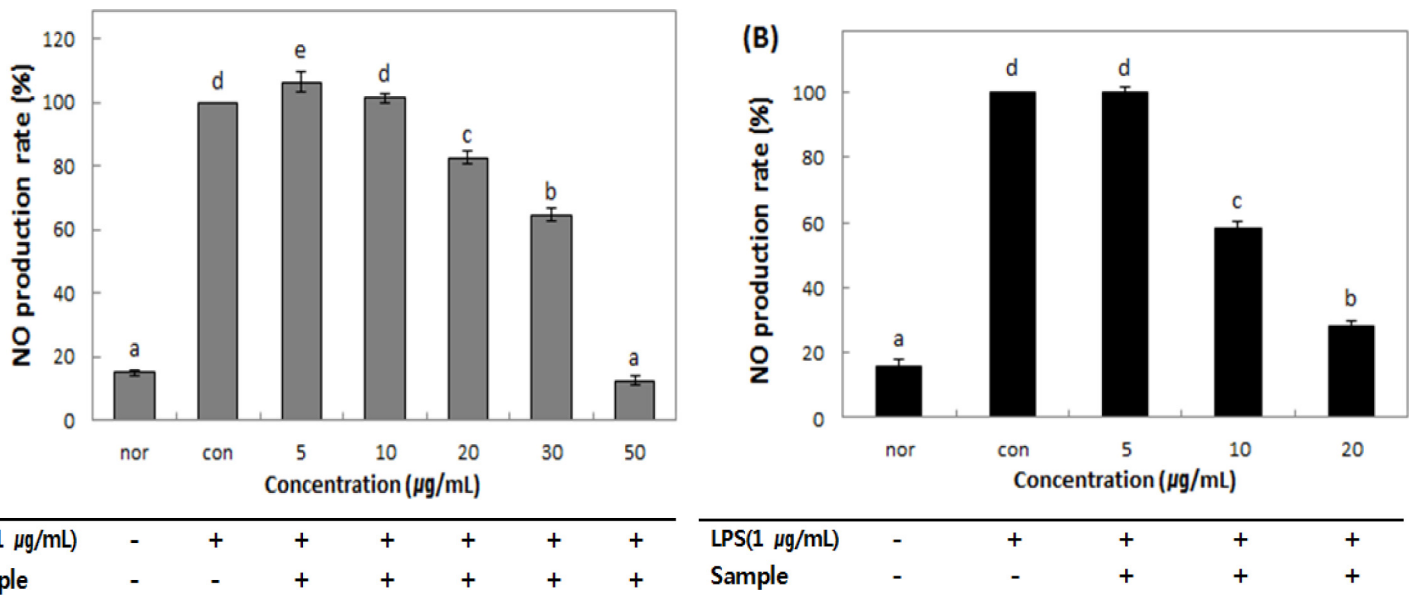

Fig. 4 Effect of $H$. ascyron extracts on nitric oxide (NO) production rate. Raw 264.7 cells were induced LPS (1 $\mu \mathrm{g} / \mathrm{mL})$ alone or in combination with H. ascyron extracts for $24 \mathrm{~h}$. The culture media of the treated cells were used to measure NO production rate. (A) Water extract, (B) $90 \%$ ethanol extract. Mean \pm standard deviation $(n=3)$. Means with different letters (a-e) above the bars are significantly different at $p<0.05$ by a Duncan's multiple range test
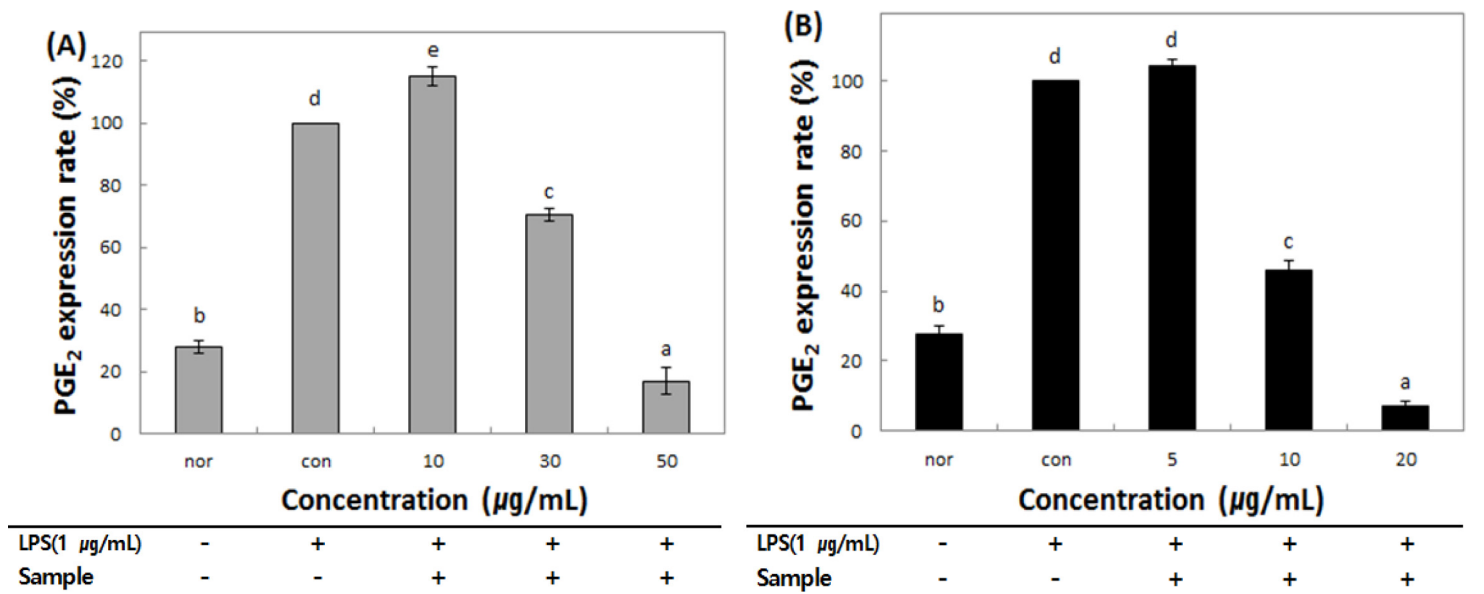

Fig. 5 Inhibitory effects of $H$. ascyron extracts on production of PGE 2 . Raw 264.7 cells were induced LPS (1 $\mu$ g/mL) alone or in combination with $H$. ascyron extracts for $18 \mathrm{~h}$. The levels of $\mathrm{PGE}_{2}$ in the cell culture media were measured by ELISA kit. (A) Water extract, (B) $90 \%$ Ethanol extract. Mean \pm standard deviation $(n=3)$. Means with different letters $(\mathrm{a}-\mathrm{e})$ above the bars are significantly different at $p<0.05$ by a Duncan's multiple range test

\section{추출물의 $\mathrm{PGE}_{2}$ 억제 효과}

$\mathrm{PGE}_{2}$ 는 $\mathrm{COX}-2$ 에 의하여 생성되며 염증반응에 동반되는 부종, 혈관 확장, 통증발생 등에 많은 영향을 주는 것으로 알려져 있 다. 또 염증성 질환뿐 만 아니라 다양한 생체반응에 있어서도 세포분열과 증식에 영향을 줌으로써 각종 질병을 유발시키거나 진행에 관여한다(Kim 등, 2010). 물레나물의 $\mathrm{PGE}_{2}$ 생성 억제 효과를 측정한 결과는 Fig. 5와 같이 나타났다. LPS 단독 처리 구 기준으로 LPS와 함께 물레나물의 열수와 $90 \%$ ethanol 추출 물을 처리하였을 때, 두 추출물 모두 농도 의존적으로 $\mathrm{PGE}_{2}$ 생 성이 유의성 있게 감소하는 경향을 보였으며, 열수 추출물의 경 우 $50 \mu \mathrm{g} / \mathrm{mL}$ 농도에서 LPS 단독 처리구에 비하여 $80 \%$ 이상 의 높은 $\mathrm{PGE}_{2}$ 생성 억제 효과를 나타내었다. $90 \%$ ethanol 추 출물 또한 $20 \mu \mathrm{g} / \mathrm{mL}$ 농도에서 $90 \%$ 이상의 매우 높은 억제 효 과를 나타냈다. Yun과 Lee(2012)는 금은화 열수와 ethanol 추출 물이 $50-200 \mu \mathrm{g} / \mathrm{mL}$ 농도에서 각각 $0.37-15.95 \%, 1.25-7.46 \%$ 로
$200 \mu \mathrm{g} / \mathrm{mL}$ 농도에서 유의적인 차이를 나타내며 $\mathrm{PGE}_{2}$ 생성을 억제하는 효과를 나타내었다고 보고하였다. 이와 비교했을 때 물레나물의 두 추출물이 매우 높은 $\mathrm{PGE}_{2}$ 생성 억제 효과를 나 타내어 우수한 염증 억제 효과를 보일 것으로 판단되었다.

\section{추출물의 iNOS와 COX-2 protein expression 억제 효과} $\mathrm{iNOS}$ 는 대식세포의 자극 때문에 생성되는 물질로 $\mathrm{NO}$ 를 합성 하는 NOS 효소의 한 종류로 다량 발현될 경우 cytokine들이 다량 분비되어 관절염, 다발성 경화증 및 천식 등의 만성 염증 질환이나 당뇨병, 심혈관 질환 등의 각종 질병을 발생시키는 것 으로 보고되어 있다(Lee 등, 2016b). COX-2는 arachidonic acid를 prostaglandin으로 변화를 촉진시키는 효소로써, 신생조직 과 염증이나 기타 면역반응 시 세포분열인자나 cytokine에 의해 염증의 부위에서 세포 내 발현이 증가하여 미생물에 의한 감염 과 손상, 혈관 확장, 암 발생에 관여한다. 주로 많은 항염증제 

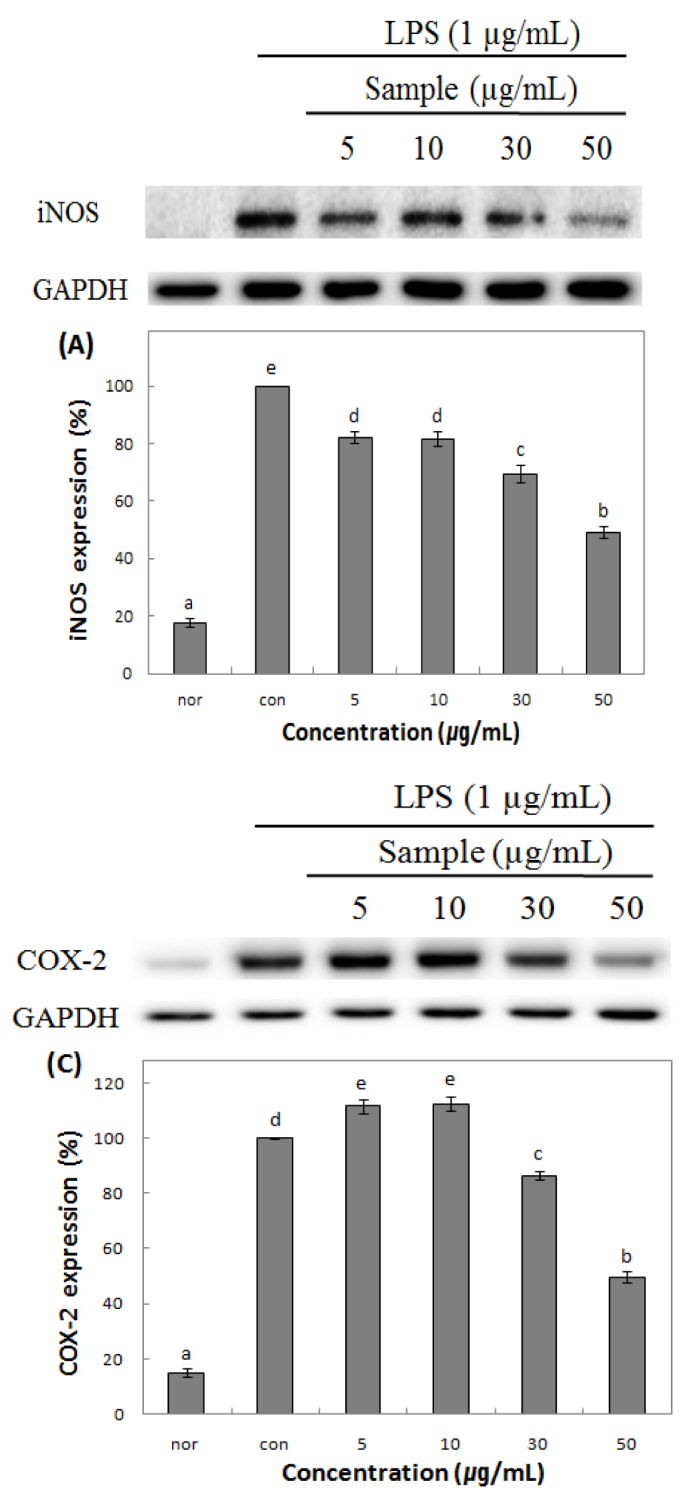
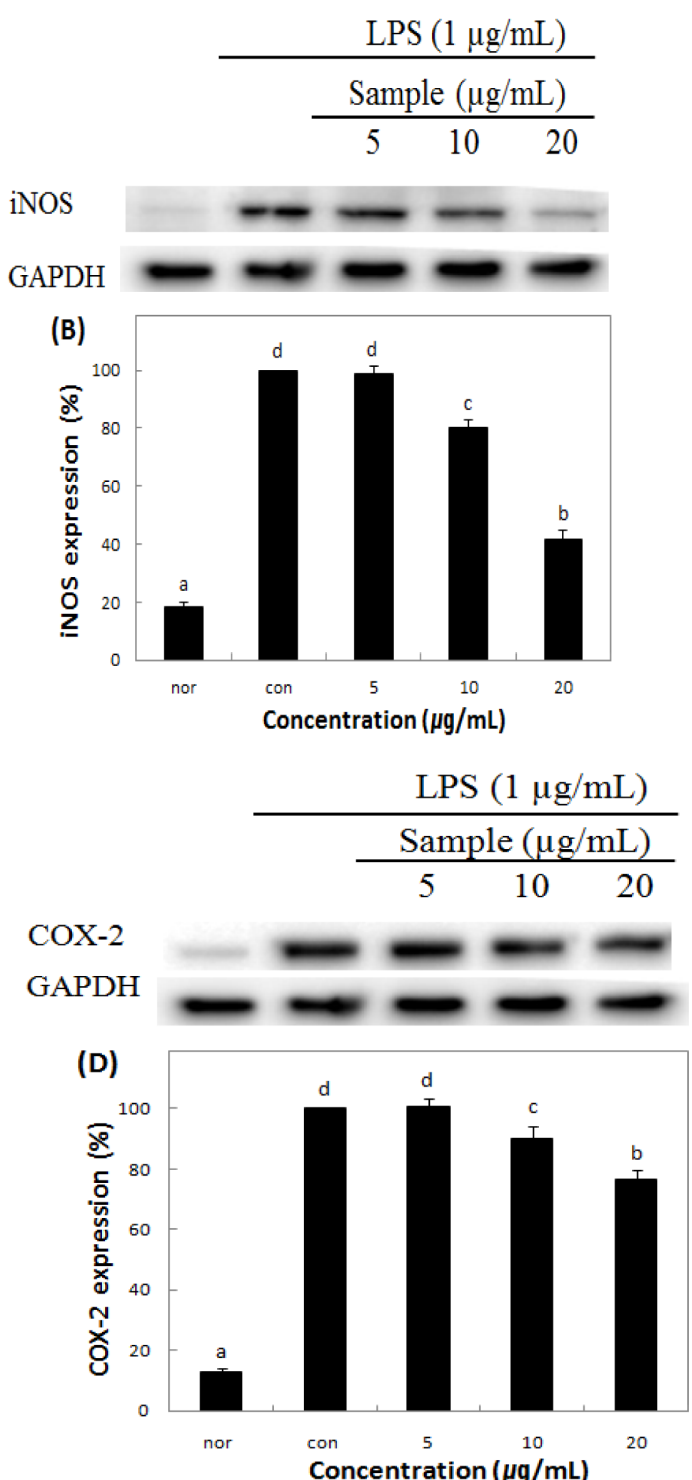

Fig. 6 Effects of H. ascyron extracts on LPS-induced iNOS and COX-2 expression. The expression levels of iNOS and COX-2 in the protein was measured after treatment of the indicated concentration of $H$. ascyron extracts and LPS ( $1 \mu \mathrm{g} / \mathrm{mL}) \mathrm{for} 18 \mathrm{~h}$. $H$. ascyron water exreacts $(\mathrm{A})$ and $90 \%$ Ethanol extract (B) on iNOS, and water extract (C) and ethanol extract (D) on COX-2. Mean \pm standard deviation $(n=3)$. Means with different letters (a-e) above the bars are significantly different at $p<0.05$ by a Duncan's multiple range test

의 작용기전은 prostaglandin 합성 억제를 통해 염증 억제 효과 를 보이며 이는 $\mathrm{COX}-2$ 의 생성과 활성 저해에 의한 것으로 보 고되어 있다(Jung 등, 2013). 따라서 물레나물 추출물의 iNOS 와 COX-2 억제 효과를 확인해 보고자 western blotting 실험을 진행한 결과 Fig. 6에서와 같이 LPS 단독 처리구 기준으로 LPS와 함께 물레나물의 열수와 $90 \%$ ethanol 추출물을 처리하 였을 때 두 추출물 모두 농도 의존적으로 $\mathrm{iNOS}$ 와 COX-2의 protein 발현을 억제하는 경향을 나타냈으며, 모두 $90 \%$ ethanol 추출물의 낮은 농도에서 높은 억제 활성을 나타내었다. iNOS 발현량은 Fig. $6 \mathrm{~A}$ 에서와 같이 열수 추출물의 경우 $50 \mu \mathrm{g} / \mathrm{mL}$ 의 농도에서 LPS 단독 처리구에 비하여 약 $50 \%$ 정도의 억제 효 과를 나타냈으며, $90 \%$ ethanol 추출물은 Fig. $6 \mathrm{~B}$ 에서와 같이 $20 \mu \mathrm{g} / \mathrm{mL}$ 의 농도에서 약 $68 \%$ 의 억제 효과를 나타냈다. $\mathrm{Kim}$
(2012)은 사백산 열수 추출물의 iNOS 억제 활성 측정결과 열 수 추출물은 최고 농도인 $400 \mu \mathrm{g} / \mathrm{mL}$ 에서 효과가 미미했고 $30 \%$ ethanol 추출물은 $100 \mu \mathrm{g} / \mathrm{mL}$ 이상에서부터 눈에 띄게 발현량이 감소했다고 보고했다. COX-2 발현량은 Fig. 6C에서와 같이 열 수 추출물의 경우 $50 \mu \mathrm{g} / \mathrm{mL}$ 의 농도에서 LPS 단독 처리구에 비 하여 약 $50 \%$ 정도의 억제 효과를 나타냈으며, $90 \%$ ethanol 추 출물은 Fig. $6 \mathrm{D}$ 에서와 같이 $20 \mu \mathrm{g} / \mathrm{mL}$ 의 농도에서 $33 \%$ 의 억제 효과를 나타냈다. 이와 비교하여 물레나물 추출물의 경우 매우 낮은 농도에서도 높은 $\mathrm{iNOS}$ 와 $\mathrm{COX}-2$ 의 protein 발현 억제 효 능을 나타내는 것을 확인할 수 있었다. 또한 $\mathrm{NO}$ 와 $\mathrm{PGE}_{2}$ 의 생 성율 저해와 유사한 pattern으로 이들의 생성에 관여하는 효소 인 iNOS와 COX-2의 protein 발현도 농도의존적으로 감소하는 양상을 확인하여 이들의 상관관계를 입증할 수 있었다. 하지만, 

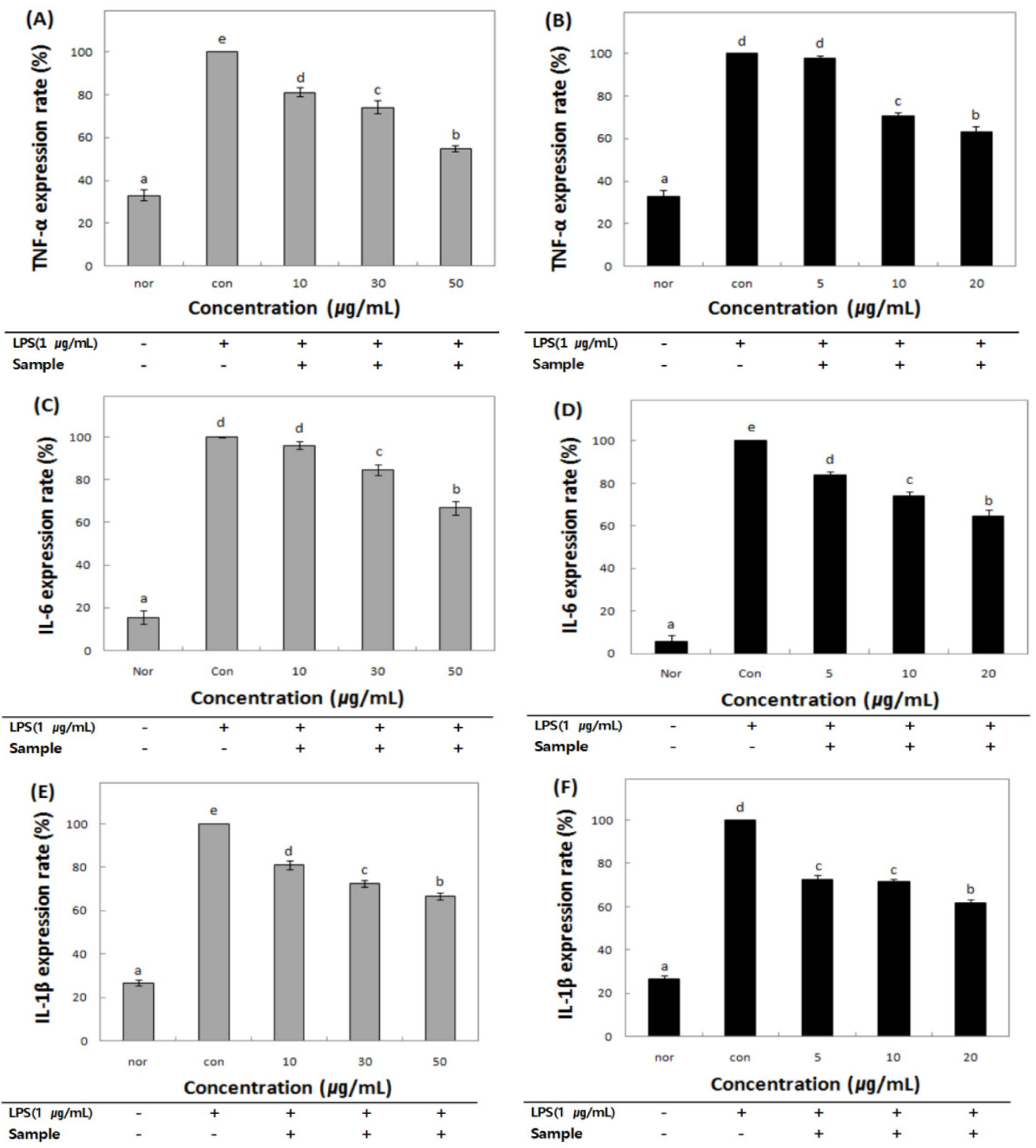

Fig. 7 Inhibitory effects of $H$. ascyron extracts on production of pro-inflammatory cytokines. Raw 264.7 cells were induced LPS (1 $\mu$ g/mL) alone or in combination with $H$. ascyron extracts for $18 \mathrm{~h}$. The levels of cytokine in the cell culture media were measured by ELISA kit. (A) TNF- $\alpha$, (C) IL-6, (E) IL-1 $\beta$ in water extract, (B) TNF- $\alpha$, (D) IL-6 (F) IL-1 $\beta$ in $90 \%$ ethanol extract. Mean \pm standard deviation ( $n=3$ ). Means with different letters (a-e) above the bars are significantly different at $p<0.05$ by a Duncan's multiple range test

동일한 농도에서 효소인 iNOS와 COX-2의 protein 발현양에 비 해 효소 산물인 $\mathrm{NO}$ 와 $\mathrm{PGE}_{2}$ 의 생성율이 다소 낮게 나타났는데, 이러한 결과는 대추 분획물을 이용한 $\mathrm{PGE}_{2}$ 생성율과 $\mathrm{COX}-2$ protein 발현 정도를 비교한 연구(Kim과 Son 2014)에서도 동일 농도에서 $\mathrm{COX}-2$ protein 발현양에 비해 $\mathrm{PGE}_{2}$ 의 생성율이 낮게 나타났다고 보고하고 있다. 이는 단백질 발현에 있어서 정성적 인 방법인 western blot 분석법에서는 각 효소의 단백질 발현 정도만 확인할 수 있는 반면, 정량적인 측정법인 ELISA 분석 법의 경우는 단백질의 발현양 뿐만 아니라 각 효소 자체가 가 지는 활성에도 영향을 받게 되어 나타나는 현상으로 판단되었 다(Kang 등, 2012). 따라서 물레나물 추출물은 효소인 iNOS와 $\mathrm{COX}-2$ 의 protein 발현을 억제하여 효소생성물인 $\mathrm{NO}$ 와 $\mathrm{PGE}_{2}$ 생성을 효과적으로 저해하는 기전을 나타내는 것을 확인할 수
있었으며 이를 통해 우수한 염증 억제 효과를 입증하였다.

\section{추출물의 Pro-inflammatory cytokine 억제 효과}

TNF- $\alpha$ 는 LPS 반응의 주요 매개체로서 분비가 증가함에 따라 열, 부종, 통증 및 홍반 등의 염증을 일으키고 지속적인 생성으 로 인해 NF- $\mathrm{KB}$ 의 활성화를 유도함으로써 염증을 발생시키며 만성 염증을 유발하여 패혈성 쇼크, 염증 등에 관여하는 것으 로 알려져 있다(Byun 2005). IL-6는 면역, 숙주 방어, 혈액 생 성 등의 중요한 기능을 하는 물질로 mitogen과 항원의 자극, LPS, calcium, cytokines, virus 등에 의해 상승되어 악성종양, 감염성 질환 등을 일으킨다(Van 1990; Hibi 등, 1996). IL-1 $\beta$ 는 T-cell의 활성화, B-cell의 성숙, NK cell의 활성을 유도하며 염증반응 시 생성되는 촉진성 cytokine으로 세균감염에 대한 염 
증성 응답의 개시 및 강화에 중요하다. 낮은 농도에서는 항상 성 유지에 필수적이나 대량 생산될 경우 T-cell을 활성화시키고 B-cell을 성숙시켜 증상을 악화시킨다(Kim 등, 2015). 따라서 물 레나물 추출물의 염증성 cytokine의 생성 억제 효과를 확인한 결과, Fig. 7에서와 같이 LPS 단독 처리구 기준으로 LPS와 함 께 물레나물의 열수와 $90 \%$ ethanol 추출물을 처리하였을 때 두 추출물 모두 농도 의존적으로 pro-inflammatory cytokines의 생 성을 억제하는 경향을 나타냈으며, TNF- $\alpha$ 억제 효과는 Fig. $7 \mathrm{~A}, \mathrm{~B}$ 에서와 같이 열수 추출물의 경우 $50 \mu \mathrm{g} / \mathrm{mL}$ 의 농도에서 LPS 단독 처리구에 비하여 약 $45.30 \%$ 정도 억제 효과를 나타 냈으며, ethanol 추출물은 $20 \mu \mathrm{g} / \mathrm{mL}$ 의 농도에서 $36.90 \%$ 의 억제 효과를 나타내었다. IL-6 저해 효과는 Fig. $7 \mathrm{C}, \mathrm{D}$ 에서와 같이 열수 추출물의 경우 $50 \mu \mathrm{g} / \mathrm{mL}$ 의 농도에서 LPS 단독 처리구 기 준으로 약 $33.00 \%$ 정도의 억제 효과를 나타냈으며, ethanol 추 출물은 $20 \mu \mathrm{g} / \mathrm{mL}$ 의 농도에서 $36.00 \%$ 의 억제 효과를 나타내어 저 농도의 ethanol 추출물이 열수 추출물 보다 높은 억제 효과 를 보였다. 열수 추출물은 $\mathrm{Kim}$ 등(2009a)이 보고한 황련해독탕 추출물 $30-300 \mu \mathrm{g} / \mathrm{mL}$ 농도에서의 IL-6의 저해 활성과 유사한 억제 양상을 나타내었으며, ethanol 추출물은 $\operatorname{Kim}(2016)$ 이 보고 한 압척초 ethanol 추출물의 $500 \mu \mathrm{g} / \mathrm{mL}$ 에서 $39.54 \%$ 의 억제 효 과와 유사한 억제 효과를 나타냈다. IL-1 $1 \beta$ 저해 효과는 Fig. $7 \mathrm{E}, \mathrm{F}$ 에서와 같이 열수 추출물의 경우 $50 \mu \mathrm{g} / \mathrm{mL}$ 의 농도에서 LPS 단독 처리구에 비하여 약 $33.30 \%$ 정도 억제 효과를 나타 냈으며, ethanol 추출물은 $20 \mu \mathrm{g} / \mathrm{mL}$ 의 농도에서 $38.30 \%$ 의 억제 효과를 나타내었다. 위의 결과와 비교했을 때 물레나물이 다른 추출물에 비해 저 농도에서 유사하거나 높은 억제 효과를 나타 내어 우수한 항염증 효과를 보일 것으로 간주되었다.

이상의 결과를 종합하면, LPS로 자극한 Raw 264.7 cell에서 iNOS, COX-2와 같은 염증성 매개체뿐만 아니라 pro-inflammatory cytokine의 생성과 발현은 물레나물의 열수와 $90 \%$ ethanol 추 출물에 의하여 농도 의존적으로 억제되는 것을 확인하였다. 물 레나물 추출물은 iNOS와 COX-2를 억제함으로써 염증 반응에 관련된 물질인 $\mathrm{NO}, \mathrm{PGE}_{2}, \mathrm{TNF}-\alpha, \mathrm{IL}-6, \mathrm{IL}-1 \beta$ 생성을 억제하 는 기전을 통하여 염증억제 효과를 나타내는 것으로 확인되었다.

\section{초 록}

물레나물(Hypericum ascyron)은 예로부터 식 - 약용으로 사용되 어져 왔으나, 물레나물의 항염증 효과와 mechanism에 대한 연 구가 매우 부족하여 물레나물 추출물의 염증 생성 반응에 관여 하는 기전을 규명하고자 하였다. 물레나물은 열수와 $90 \%$ ethanol 추출물에서 각각 $29.75,31.82 \mathrm{mg} / \mathrm{g}$ 으로 높은 phenolic 함량을 나타내었다. 물레나물 추출물의 hyaluronidase 저해 활성 을 측정한 결과 $50-200 \mu \mathrm{g}$ phenolics $/ \mathrm{mL}$ 농도에서 열수와 $90 \%$ ethanol 추출물이 각각 $0.00-14.81,15.33-47.49 \%$ 의 저해 활성을 나타내어 항염증 효과가 있는 것으로 판단되었다. 물레나물 추 출물의 세포 독성을 측정한 결과, 열수와 $90 \%$ ethanol 추출물 에서 각각 $30-100 \mu \mathrm{g} / \mathrm{mL}$ 농도에서 독성이 관찰되어 열수 추출 물의 농도 구간을 $10-50 \mu \mathrm{g} / \mathrm{mL}$, ethanol 추출물은 $5-20 \mu \mathrm{g} / \mathrm{mL}$ 으로 선정하였다. LPS로 자극한 Raw 264.7 cell에서 iNOS, COX-2와 같은 염증성 매개체뿐만 아니라 pro-inflammatory cytokine의 생성과 발현은 물레나물의 열수와 $90 \%$ ethanol 추 출물에 의하여 농도 의존적으로 억제되는 것을 확인하였다. 물 레나물 추출물의 염증 억제 효과는 $\mathrm{iNOS}$ 와 $\mathrm{COX}-2$ 를 억제함으 로써 염증 반응에 관련된 물질인 $\mathrm{NO}, \mathrm{PGE}_{2}, \mathrm{TNF}-\alpha, \mathrm{IL}-6$, $\mathrm{IL}-1 \beta$ 생성을 억제하는 기작을 가지는 것으로 판단되었다. 따라 서 물레나물 추출물은 다양한 염증성 질환에서 매개 물질들의 과발현에 의해 야기되는 질병을 치료하기 위한 치료제로 다양 하게 활용할 수 있는 천연물 소재로 사용될 수 있을 것으로 판 단되며, 물레나물의 기능성 식품 산업화를 위한 유용한 기초 자 료가 될 수 있을 것으로 판단되었다.

Keywords 대식세포 - 물레나물 - 사이토카인 · 페놀성 화합물 항염증 효과

\section{References}

Byun BH (2005) Effect of Inonotus obliquus ethanol extract on cytokine Expression in Raw 264.7 cell. Kor J Herbology 20: 55-60

Carmichael J, Degraff WG, Gazdar AF, Minna JD, Mitchell JB (1987) Evaluation of a tetrazolium-based semiautomated colorimetric assay: assessment of chemosensitivity testing. Cancer Res 47: 936-942

Cha BC, Lee EH (2004) Antioxidant and antiinflammation Activities of Prunus persica tree extracts. Korean J Medicinal Crop Sci 12: 289-294

Cho KS (2015) Evaluation of Achyranthes japonica ethanol extraction on the inhibition effect of hyaluronidase and lipoxygenase. Journal of life science 25: 1370-1376

Cho YJ (2012) Characterization of biological activities of Rehmannia glutinosa extracts. J of Life science 22: 943-949

Cho YJ, Ju IS, Chun SS, An BJ, Kim JH, Kim MU, Kwon OJ (2008) Screening of biological activities of extracts from Rhododendron mucronulatum turcz. flowers. J Korean Soc Food Sci Nutr 37: 276-281

Dangne HM, Hanson J, Supuran C, Pratico D (2006) Coxibs and cardiovascular side-effect: from light to shadow. Currpharm Des 12: 917-975

Folin O, Denis W (1921) On phosphotungastic-phosphomolybdic compounds as color reagents. J Biol Chem 12: 239-243

Han JS, Lee JY, Baek NI, Back IW, Shin DH (2002) Isolation of growth inhibition substance on food borne microorganisms from Hypericum ascyron L. and application to food preservation. Korean J Food Ssi Technol 34: 274-282

Hibi M, Nakajima K, Hirano T (1996) IL-6 cytokine family and signal transduction: a model of the cytokine system. J Mol Med 74: 1-12

Jeong HJ, Lee KY, Hong SY, HEO NK, Kim HY (2013) Anti-inflammatory effects of Xanthoceras Sorbifolia seeds oil on Raw 264.7 macrophages and TPA-induced ear edema mice. J of Forest Sci 29: 324-330

Jhoo JW (2008) Anti-inflammatory effects of purpurogallin carboxylic acid, an pxidation product of gallic acid in fermented tea. Korean J Food Sci technol 40: 707-711

Jo JB, Lee EH, Cho YJ (2016) Beauty food activities of isolated compounds from Tetragonia tetragonioides. J Korean Soc Food Sci Nutr 45: 333341

Joo EY, Lee YS, Kim NW (2007) Polyphenol compound contents and physiological activities in various extracts of the Vitex rotundifolia stems. J Korean Soc Food Sci Nutr 36: 813-818

Jung YS, Eun CS, Jung YT, Kim HJ, YU MH (2013) Anti-inflammatory effects of Picrasma quassioides (D.DON) BENN leaves extracts. Journal of Life Science 23: 629-636

Kang Ch, Choi YH, Choi IW, Lee JD, Kim GY (2011a) Inhibition of lipopolysaccharide-induced iNOS, COX-2, and TNF- $\alpha$ expression by aqueous extract of Orixa Japonica in raw 264.7 cells via suppression of 
NF- $\kappa$ B activity. Trop J P harm Res 10: 161-168

Kang SW, Han BK, Lee TH, Kim EJ, Lee GP (2012) Identification of Introduced Gene and Its Expression and Gene Stability Assessment for Event Selection of Genetically Modified Plant toward Approval: Cucumber Mosaic Virus Resistant Hot Pepper. Kor J Hort Sci Technol 30: 192-200

Kang WY, Song YL, Zhang L (2011b) $\alpha$-glucosidase inhibitory and antioxidant properties and antidiabetic activity of Hypericum ascyron $\mathrm{L}$. Med Chem Res 20: 809-816

Kim DH, Park SJ, Jung JY, Kim SC, Byun SH (2009a) Anti-inflammatory effects of the aqueous extracts of Hwangnyeonhaedok-tang in LPSactivated macrophage cells. Kor J Herbology 24: 39-47

Kim JH (2016) Anti-inflammatory effect of Commelina communis extract on lipopolysaccharide-stimulated macrophages. Dissertatiom, Wonkwang University

Kim JS (2012) Comparative study on the anti-inflammatory effects of the water and 30\% EtOH extracts of Sabaek-san. Dissertatiom, Wonkwang University

Kim KP, Kwon HO, Han SM, Lee JM, Cho YH (2014) Inhibitory effect of korean royal jelly on inflammatory response in lipopolysaccharidestimulated peritoneal macrophages. J Apic 29: 153-159

Kim MJ, Bae NY, Kim KBWR, Park JH, Park SH, Cho YJ, Ahn DH (2015) Anti-inflammatory effect of water extract from tuna heart on lipopolysaccharide-induced inflammatory responses in raw 264.7 cells. Korean Society for Biotechnology and Bioengineering Journal 30: 326333

Kim MK, Kim DY (2015) Anti-inflammatory effect of barley leaf ethano extract in LPS-stimulated RAW264.7 macrophage. Korean J Food Preserv 22: 735-743

Kim SI, Sim KH, Ju SY, Han YS (2009b) A study of antioxidative and hypoglycemic activities of Omija(Schizandra chinensis Baillon) extract under variable extract conditions. J Korean Soc Food Sci Nutr 22: 41-47

Kim TH, KO SS, Park C, Park SE, Hong SH, Kim BW, Choi YH (2010) Anti-inflammatory effects of Nerium indicum ethanol extracts through suppression of NF-kappaB activation. Journal of Life Science 20: 12211229

Kim YJ, Son DY (2014) Inflammatory mediator regulation of the Zizyphus jujube leaf fractions in the LPS-stimulated Raw264.7 mouse machrophage. Korean J Food Preserv 21: 114-120

Kushwah A, Amma K, Sareen N (1978) Effect of some anti-inflammatory agents on lysosomal \& testicular hyaluronidase. Indian J Exp Biol 16: 222-224

Lee SH, Kwon MJ, Kim SY, Sohn HY, Shin WC, Kim JS (2016a) Suppressive effects of lees from sweet potato soju on LPS-induced inflammatory responses in raw 264.7 cells. Journal of Life Science 26: 117-122

Lee SJ, Lee DG, Kim MY, Kong SC, Yu KH, Kim YY, Lee SH (2016b) Enhancement of anti-inflammatory activity by fermentation of Sargassum siliquanstrum. Journal of Life Science 26: 318-324

Makins R, Ballinger A (2004) Gastrointestinal side effect of drugs. Expert Opin Drug Saf 2: 421-429

Moncada S, Palmer R, Higgs E (1991) Nitric oxide: physiology, pathophysiology and pharmacology. Pharmacol Rev 43: 109-142

Nam HH (2014) Antioxidant and anti-inflammatory effect in LPS-induced RAW 264.7 cells of Agrimonia coreana extracts. Dissertatiom, Chonbuk National University

Park HJ, Kwon SH, YUN SY, Lee KT (2000) Isolation of steroids and flavonoids from the herbs of Hypericum ascyron L. Kor J Pharmacogn 31: $39-44$

Reissig JL, Storminger JL, Leloir LF (1995) A modified colorimetric method for the estimation of N-acetylamino sugars. J Biol Chem 217: 959-966

Ryu IH, Cho HB, Kim SB, Seo YJ, Choi CM (2011) The inhibitory effect of Picrasmae Lignum on inflammatory responses. J Korean Obstet Gynecol 24: $1-014$

Tak PP, Firestein GS (2001) NF-кB: A key role in inflammatory diseases. J Clin Invest 107: 7-11

Van SJ (1990) Interleukin-6: an overview. Annu Rev Immunol 8: 253-278

Yoon SB, Han HS, Lee YJ (2011) Effect of Scutellariae Radix extract on the proinflammatory mediators in RAW 264.7 cells induced by LPS. Kor J Herbology 26: 75-81

Yun KJ, Lee EY (2012) Effect of hot aqueous and ethanol extracts from Lonicera japonica flos on $\mathrm{NO}$ and $\mathrm{PGE}_{2}$ in macrophage. The $\mathrm{J}$ of Kor Acupuncture \& Moxibustion Society 29: 67-74 